\title{
AN OVERVIEW OF THE EUROPEAN ENERGY POLICY EVOLUTION: FROM THE EUROPEAN ENERGY COMMUNITY TO THE EUROPEAN ENERGY UNION
}

\author{
Oana Poiană, Ph.D \\ Babeș-Bolyai University Cluj-Napoca, \\ Romania
}

\begin{abstract}
The current study attempts to provide a comprehensive analysis of the European energy policy evolution emphasizing the centrality of energy resources for the entire EU's integration process. The results reveal that for the last decade EU had a rather reactionary behaviour instead of a proactive energy security strategy. EU's dependence on natural gas imports has been the main driver of its energy security strategy and the post gas crisis moments represented the periods when the level of energy insecurity prompted higher levels of solidarity between member states, which in turn allowed for major advancements towards the creation of the current Energy Union.
\end{abstract}

Keywords: Energy Union, European Energy Policy, Energy security

\section{Introduction}

Over the past two hundred years, energy has evolved as one of the dominant themes of international affairs gaining continuous centrality due to a series of events that indicated its undeniable importance to human welfare. As the living standards begun to rise, energy become vital for the functioning of all sectors (lighting and heating services, industry, transport, agriculture, scientific development, etc.) and the amount of consumed resources increased as each of these sectors continued to develop. The growing demand for energy at the global level, the climate change, the energy market volatility, the regional deficits of supply together with the increased dependence on imported resources represent only few 
factors that have stressed over the years not only the strategic aspect of the energy sector, but also the importance of coordinated action for achieving common regulations for managing resources. However, energy policies have been and continue to be on a great extent the prerogative of the nation states since they prefer to individually secure their access to resources through negotiations that often reflect divergent interests and priorities. Perhaps one of the most relevant cases in this respect is represented by the numerous attempts made by the EU member state toward achieving a common European energy policy. If we are to analyse the role of energy for the European integration process, we must recognize the unequivocal pre-eminence of energy resources throughout the entire process.

The importance of securing energy resources represented from the very beginning the driving force of the integration process and over time this issue has become deeply rooted in the European construction. More than sixty years ago, EU's six founding member states established their economic agendas based on energy resources and the process of integration that followed was characterized by numerous initiatives meant to construct the fundaments of a common European energy policy. Paradoxically, despite its prevalence, energy policy at EU level has failed to develop into a coherent common policy that can guarantee energy security for all member states. Despite all these efforts, energy security currently represents one of the most problematic areas of public policy at European level (Solorio and Morata, 2012).

Unlike other EU policies, EU's energy policy is difficult to conceptualize given that until recently this policy was not officially recognized as being a fully-fledged EU policy. Therefore, when talking about EU energy policy we are referring to a greater extent to the total amount of efforts made by the EU and its member states towards achieving a coordinated action in the energy field and to a lesser extent to a comprehensive and robust policy that went through all the policy conceptualization stages (agenda setting, policy formulation, policy decisions and the actual implementation). Although the EU energy 
policy and the national policies of the member states share relatively the same purpose, namely that of obtaining energy security at an affordable price, EU's energy policy agenda additionally seeks to create an internal energy market and to develop a low carbon economy.

These three European energy policy branches are intertwined with other policy areas: the liberalization of the internal market represents a part of the single market project being strongly influenced by competition policy; the climate change combines energy with environmental concerns while energy security is related to the foreign and security policy of the European Union (Wallace and Pollock, 2010). During the last decade the energy security element has been the most discussed aspect of the EU energy policy mostly because of the increasing energy dependency of member states on Russian imported resources and the numerous crisis caused by the Russian gas cut offs. The next section of this study infers that the most notable developments within the European energy policy have been made in response to these crises.

\section{The sinuous path of the European Energy Policy ${ }^{22}$}

When the six founding states decided in 1951 to sign the Treaty establishing the European Coal and Steel Community (ECSC), energy was a key topic on their political and economic agendas. In order to increase cooperation and strengthen the European Community six years after this memorable event, another energy based institution was established, the European Atomic Energy Community (EURATOM). Sixty years later, energy has never been higher on EU's agenda (Andoura et al., 2010). Consequently, during

\footnotetext{
${ }^{22}$ This section includes one verbatim quoted passage from previous published research quoted below: Poiana O. (2010), A Constructivist Approach to the security of the European Natural Gas Supply. The Black Sea Region and its Geopolitical Significance, Germany: VDM Publishing House, pp. 4-14
} 
the last decades the European Union has launched multiple initiatives meant to increase energy security for all its members. These initiatives took the form of official documents, green papers, policies, energy provisions of the Lisboan Treaty and finally the newly crafted Energy Union.

Back in 2000, the first "Green Paper" issued by the European Commission was warning about the fact that in the next two or three decades, the European Union will have to import up to $70 \%$ of its natural gas demand, $90 \%$ of its oil demand and $100 \%$ of its coal demand (EU Green Paper, 2000). According to the European Energy Security Strategy issued in 2014, the global energy demand is expected to grow by $27 \%$ by 2030 . EU imports half of the energy it consumes paying more than $1 €$ billion per day. Its import dependency has reached more than $90 \%$ for oil and $66 \%$ for natural gas.

Recent statistics show that many member states are heavily reliant on just one source of supply while several are entirely reliant on Russia for their natural gas. Moreover, in 2013 EU has imported 39\% of its natural gas from Russia which accounted for $27 \%$ of its gas consumption (European Energy Security Strategy, 2014). Moreover, according to the French international association for gas, Cedigaz, the gas imports from Russia and Central Asia to Europe through pipelines is expected to grow since European natural gas production "is expected to decline 2.1 percent per year to170 bcm/year by 2035, while demand is forecast to inch up 0.6 percent over the same period (Offshore Aberdeen, 2015)."

This data together with the increasing number of energy crisis urge for a rapid formulation and implementation of a common European Energy Union which would focus not only on the European energy market fulfilment but one that would also take into consideration a series of other important factors such as the reliability of the main energy sources, instability of transit routes, geopolitical elements and the dynamics of the political environment (Umbach, 2017). However, the realization of this plan appears to be an 
Issue no. $22 / 2017$

extremely difficult task, given the diverse energy interests of member states which for the moment impede effective cooperation.

Although the energy security issue was part of the European agenda for so many years, the European Union has only relatively recently showed a real interest in adopting a series of policy initiatives that aim to create a Common European Energy Security Policy. This tardily decision to create a legal and economic framework of cooperation in the European energy system can be explained partially by the absence of serious energy supply threats since the oil embargoes in 1973-1974. Therefore, Europe has centred all its initiatives on liberalization of electricity and gas markets through Gas Directive 98/30/CE and Electricity Directive 96/92/CE (Helm, 2004). The European internal energy market has been further consolidated by the Directive 2003/54/EC (concerning Common Rules for the Internal Market in Electricity) and Directive 2009/73/EC EC (concerning Common Rules for the Internal Market in Natural Gas) which repeals the 2003/55/ Directive.

According to Helm, the effect of all these initiatives did not create an integrated market in Europe; on the contrary, it led to a series of national markets with bilateral connections (Helm, 2004). Another important step towards the completion of the European energy market was the 2005 Energy Community Treaty, which aimed "to create a legal framework for an integrated European market for electricity and gas and to establish a regional energy market that is compatible with the internal energy market of the European Union (International Energy Agency, 2008, p. 35)."

Although this market related policy objectives have brought some benefits, the European Union shifted its strategy towards the realization of a common external energy policy and focused its future policy initiatives also on other significant issues, such as climate change and its dependency on imported energy supply. This shift can be clearly observed if we look at the 2006 European Union Green Paper which aimed not only to "complete the internal European gas and electricity markets, to create solidarity between member states in order to enhance a more sustainable, efficient and diverse energy mix and 
to create an integrated approach to tackle climate change" but also to "establish a strategic European energy technology plan and a coherent external energy policy (Haghighi, 2007, p.172)." Additionally, this policy claimed that the best way to achieve energy security is to create a "pan-European energy community, a common regulatory space around Europe (Youngs, 2009, p. 30)." However, the scope of the Green Papers was only to initiate discussions on a specific topic and encourage further negotiations between the actors. That is why they are perceived as "soft law" instruments which cannot lead to concrete implementation of the discussed projects (Haghighi, 2007).

Beginning with 2007 EU assumed a more resolute tone concerning the energy issues by drafting an energy strategy aimed at regulating the gas distribution and production activities. Following the increase of Russia's influence in the energy sector and its obvious wish to become an energy hegemon, this was seen as EU's first serious attempt towards its future energy diversification plans (Koinova, 2008). The "Energy and Climate Package" included the "20-20-20" energy policy formula that aimed at reducing Green House Gas Emissions, raise the share of renewable and increase energy efficiency. Although this represented another important step towards the creation of the European energy policy, its implementation revealed that member states were not yet able to commonly address the energy issues but proffered instead to deal with them at a national level (Umbach, 2011)

Thus, whereas some visible progress has been made in terms of sustainability of the internal market, the creation of an External European Energy Policy had still a long way to go. For the last decades Europe relied too much on markets and this determined member states to form bilateral relations with the main energy supplier countries rather than uniting their forces for creating a Common European Energy Policy.

As it was stated in the summary of a recent policy dialog concerning the new European Union Energy Policy, the market cannot provide the solution to the security of supply issue and the only viable method to address it lies in "Europe negotiating with 
external energy suppliers with a unitary voice, reducing energy consumption and expanding domestic production (European Policy Centre Report, 2007)." After the ratification of the Lisbon Treaty, Europe gained a sense of symbolic unity which supported the European Union in its attempt to reverse the asymmetric interdependence which is favouring Russia. Furthermore, the Lisbon Treaty is the first Treaty that includes clear provisions on energy issue. The article 194 TFEU of the Treaty asserts that: Union policy on energy shall aim, in a spirit of solidarity between Member States, to: (i) to guarantee the functioning of the energy market, (ii) to ensure 'security-of-supply' of the Union, (iii) to promote energy efficiency and the development of new and renewable forms of energy, and finally (iv) to promote the interconnection of energy networks (The Lisbon Treaty, 2007).

As a result of the January 2009 Russian gas cut-off and the rapid development of South Stream pipeline, the European Commission proposed the Third Energy Market Package and after long negotiation, the European Parliament and the Council agreed to adopt it in June 2009. The new legislation introduced two new directives concerning the liberalization of electricity and gas markets and created in 2010 the "Agency for the Cooperation of Energy Regulators "(ACER) as an independent body from the Commission which will assist the National Regulatory Authorities in implemented the new regulatory framework within member states (Andoura et al., 2020) .

Just few months before the beginning of the second "gas war", the Commission adopted the "EU Energy Security and Solidarity Action Plan" which included the launching of the Southern Gas Corridor. This new strategic perspective has been perceived as a modern Silk Road which entailed a plan for enhancing the diversification objective by constructing LNG (liquefied natural gas) receiving terminals in Central and South-East Europe and pursuing the $4^{\text {th }}$ corridor (SGC) in order to bring gas from Caspian and Middle Eastern producing countries to the EU (Hafner, 2015, para. 3)."

Back then, Nabucco pipeline represented the flagship project of the SGC but since its launching in 2002, the project encountered many commercial and financial setbacks and 
was in direct competition with Gazprom's project, the South Stream pipeline. Consequently, Nabucco Consortium proposed a shorter version called Nabucco West. However, in 2014 both projects were cancelled.

Meanwhile, Azerbaijan and Turkey agreed in 2011 to construct a $2000 \mathrm{~km}-\mathrm{long}$ gas pipeline that aims to transport Azeri gas to $6 \mathrm{bcm} / \mathrm{year})$ Turkey and (10/bcm/year) Europe by the end of 2019. Following Nabucco's cancelation, Trans Anatolian Natural Gas Pipeline (TANAP) became the central project of EU's plan to reduce its dependence on Russian gas.

TANAP will receive gas from the South Caucasus Pipeline (SCP), an already functional pipeline that transports gas from Shah Deniz field to Turkey and from there TANAP will connect to the Trans Adriatic Pipeline (TAP) in order to transport Azeri gas to Southern Italy. EU (Hafner, 2015).

Another important measure introduced by EU Commission with the aim of updating the existing infrastructure and building a new one including interconnectors, was its decision to create a list of 248 energy infrastructure projects of common interest (PCIs) involving mainly electricity and gas transmission lines (which will "benefit from accelerated licensing procedures, improved regulatory conditions, and access to financial support totalling $€ 5.85$ billion from the Connecting Europe Facility (CEF) between 2014 and 2020 (European Commission Projects of common interest, 2015). ” 
Issue no. $22 / 2017$

Table 7-Southern Gas Corridor: proposed projects

\begin{tabular}{|c|c|c|c|c|c|}
\hline $\begin{array}{l}\text { PROJECT } \\
\text { NAME }\end{array}$ & $\begin{array}{l}\text { START- / } \\
\text { ENDPOINT }\end{array}$ & $\begin{array}{l}\text { CAPACITY/ } \\
\text { ESTIMATED } \\
\text { COSTS }\end{array}$ & SOURCE OF GAS & $\begin{array}{l}\text { PROJECT } \\
\text { PARTNERS }\end{array}$ & STATUS \\
\hline Nabucco & Turkey - Austria & $\begin{array}{l}10-31 \mathrm{bcm} / \mathrm{y} \\
€ 7.9-15 \mathrm{bn}\end{array}$ & $\begin{array}{l}\text { Azerbaijan, } \\
\text { (Iraq, Iran) }\end{array}$ & $\begin{array}{l}\text { BOTAS, RWE, } \\
\text { Bulgargaz, } \\
\text { Transgaz, } \\
\text { MOL, OMV }\end{array}$ & Abandoned \\
\hline $\begin{array}{c}\text { Nabucco } \\
\text { West }\end{array}$ & $\begin{array}{c}\text { Bulgaria/ } \\
\text { Turkey - Austria }\end{array}$ & $\begin{array}{l}10-23 \mathrm{bcm} / \mathrm{y} \\
\text { Not specified }\end{array}$ & Azerbaijan & $\begin{array}{c}\text { BEH, BOTAS, } \\
\text { FGSZ, } \\
\text { GDF Suez, } \\
\text { Transgaz, } \\
\text { OMV }\end{array}$ & $\begin{array}{l}\text { Abandoned, } \\
\text { although may } \\
\text { resurface }\end{array}$ \\
\hline TAP & Greece - Italy & $\begin{array}{l}10-20 \mathrm{bcm} / \mathrm{y} \\
€ 1.5-3.9 \mathrm{bn}\end{array}$ & Azerbaijan & $\begin{array}{l}\text { BP, SOCAR, } \\
\text { Statoil, } \\
\text { Fluxys, Total, } \\
\text { E.ON, Axpo }\end{array}$ & $\begin{array}{c}\text { Reing } \\
\text { implemented, } \\
\text { expected } \\
\text { to come on } \\
\text { stream } 2019\end{array}$ \\
\hline TANAP & $\begin{array}{c}\text { Turkey/Georgia } \\
\text { - Greece \& } \\
\text { Bulgaria }\end{array}$ & $\begin{array}{c}16-31 \mathrm{bcm} / \mathrm{y} \\
-€ 7.4 \mathrm{bn}\end{array}$ & Azerbaijan & $\begin{array}{l}\text { BOTAS, } \\
\text { SOCAR }\end{array}$ & $\begin{array}{c}\text { Being } \\
\text { implemented, } \\
\text { expected } \\
\text { to come on } \\
\text { stream } 2019\end{array}$ \\
\hline TCGP & $\begin{array}{l}\text { Turkmenistan } \\
\text { - Azerbaijan }\end{array}$ & $\begin{array}{l}30 \mathrm{bcm} / \mathrm{y} \\
\sim € 3.7 \mathrm{bn}\end{array}$ & Turkmenistan & Not clear & On hold \\
\hline $\begin{array}{l}\text { White } \\
\text { Stream }\end{array}$ & $\begin{array}{l}\text { Azerbaijan } \\
\text { - Romania }\end{array}$ & $\begin{array}{c}8-32 \mathrm{bcm} / \mathrm{y} \\
€ 4.5 \mathrm{bn}\end{array}$ & $\begin{array}{l}\text { Azerbaijan, } \\
\text { Turkmenistan }\end{array}$ & $\begin{array}{c}\text { White Steam } \\
\text { Pipeline } \\
\text { Company } \\
\text { Ltd. (UK), } \\
\text { GUEU (US) }\end{array}$ & Not clear \\
\hline $\begin{array}{l}\text { South } \\
\text { Stream }\end{array}$ & Russia - Italy & $\begin{array}{c}63 \mathrm{bcm} / \mathrm{y} \\
€ 19-24 \mathrm{bn}\end{array}$ & Russia & $\begin{array}{c}\text { Gazprom, } \\
\text { EDF, } \\
\text { Wintershall, } \\
\text { ENI }\end{array}$ & Suspended \\
\hline Poseidon & Greece - Italy & $\begin{array}{l}8 \mathrm{bcm} / \mathrm{y} \\
€ 500 \mathrm{mio} .\end{array}$ & Azerbaijan & Edison, DENA & Not clear \\
\hline
\end{tabular}

Source: Sami Andoura \& Jean-Arnold Vinois, "From the European Energy Community to the Energy Union. A policy proposal for the short and the long term", Notre Europe, 2015, p. 88 
Issue no. 22/2017

Given the complex interdependences between EU and Russia, the two actors signed in March 2013 a roadmap on energy cooperation which aims to develop long term RussiaEU cooperation in energy sector and create a pan-European energy market by 2050. However, while EU's plan includes the creation of a transparent and competitive integrated network infrastructure, Gazprom's energy practices over the last decade seem to promote the exact opposite of this goal.

Furthermore, acknowledging the deterioration of EU-Russia relationship in the context of the Ukrainian crisis and the potential risk concerning its Russian gas imports, EU has launched in May 2014 a European Energy Security Strategy based on eight key pillars that call for increased solidarity and a closer cooperation in the energy filed between EU member states:

1. Immediate actions aimed at increasing the EU's capacity to overcome a major disruption during the winter 2014/2015;

2. Strengthening emergency/solidarity mechanisms including coordination of risk assessments and contingency plans; and protecting strategic infrastructure;

3. Moderating energy demand;

4. Building a well-functioning and fully integrated internal market;

5. Increasing energy production in the European Union;

6. Further developing energy technologies;

7. Diversifying external supplies and related infrastructure;

8. Improving coordination of national energy policies and speaking with one voice in external energy policy (European Energy Security Strategy, 2014).

As it can be easily inferred by now, the moments when EU has taken serious measures towards reinforcing its energy security have coincided with the moments Russia decided either to cut off gas supply to Europe or endanger the energy transit by intensifying the conflict in Ukraine. 2014 has definitely been a year of monumental change that brought a new strategic realignment, in particularly in terms of natural gas transportation projects. Not only that we have witnessed a dramatic conflict escalation in 
Ukraine, the dismissal of Nabucco and the cancelation of its competitor, the South Stream project, but towards the end of the year, it has become clear that Turkey will be the main transit country for energy resources coming from Russia and the Caspian area to the European market.

All these events have created a sense of urgency concerning the launching of the long postponed European Energy Union. Likewise, the 2014 European Energy Security Strategy paved the way for harmonizing the European energy interests and strengthen the European energy security which despite increased regulatory activity during the last decade, "has been undermined by an internal challenge: short-sighted national interests, power generating companies' fear of competition, a patchwork of national mini-markets, and a lack of political cohesion, cooperation and solidarity (Hedberg, 2015)."

According to the realist and neorealist approaches, "state preferences are fixed and uniformly conflictual. Interstate politics is thus a perpetual interstate bargaining game over the distribution and redistribution of scarce resources (Legro and Moravcsik, 1999, p. 3).” Taking into consideration the level of discrepancy between the energy surplus and deficit EU member states, it is evident why moving from words to practice in accomplishing a common energy policy has been such a struggle. Thus, the newly crafted Energy Union represents probably the most serious and ambitious attempt to unify 28 different national regulatory framework for creating an integrated European energy market according to a three years action plan. The Union launched on $25^{\text {th }}$ of February 2015 is based on five major objectives concerning the:

1. Energy security, solidarity and trust;

2. Creation of a fully integrated European energy market;

3. Energy efficiency contributing to moderation of demand;

4. Decarbonising the economy;

5. Research, Innovation and Competitiveness (Energy Union Package, 2015). 
Reiterating the importance of a stricter enforcement of the already existing EU legislation, the current Vice-President of the Commission, Maroš Šefčovič, stated that the Energy Union will ensure that the intergovernmental gas contracts will fully comply with EU law, and it will bring more transparency in commercial contracts (Matalucci, 2015). Additionally, the Commission intends to diversify the energy supply import by financially assisting the construction of more LNG terminals and pipelines. The Energy Union represents for the moment just a vision marking only the start of a long process that will necessitate strategic thinking and a good use of energy diplomacy.

\section{Conclusion}

As it has been illustrated, European Union measures in the energy field primarily focused on internal market completion and gradually moved towards the creations of an external energy policy as its energy supply dependence increased. The major factors that urged the European Community to adopt a series of important measures for securing its energy supplies, were the insecurity experienced in the aftermath of Russian gas cut-offs of January 2006/2009 and the recent dismissal of Ukraine as an energy corridor because both signalled the worsening of the geo-political setting that could have future dramatic effects on the European natural gas trade.

However, the European energy policy has significantly developed during the last decade and it became one of the few EU successful strategic stories. Currently, Russia provides only one-third of Europe's gas and the majority of the member states are able to withstand a potential gas cut off. The Third Energy Package has challenged Gazprom's business pattern by promoting higher degrees of transparency, competitiveness and liberalization in the energy cooperation process while EU has showed an increased interest in accelerating its grid interconnectivity (Dudău, 2014). Moreover, starting with 2020, the TANAP-TAP pipeline tandem which for many appeared to be a "never-ending odyssey" 
will complete EU's Southern Gas Corridor diversification strategy strengthening thus the European supply security (Hafner 2015).

Finally, probably the boldest EU decision is the recently launched Energy Union that has been intensely discussed for the last decade. Although it will take a great deal of effort, time and money to harmonise the national energy policies of the member states, EU should not lose the momentum created by the current low oil and gas prices, and build an European integrated market.

\section{References}

- ANDOURA, S., et al. (2010), “Towards a European Energy Community A Policy Proposal". Notre Europe, available at: http://www.institutdelors.eu/media/etud76energy-en.pdf?pdf=ok, (accessed 11.02.2017).

- DUDĂU, R. (2014), "The Ukraine crisis: Legal and energy security impacts in the Black Sea Basin”. Caspian report.

- European Commission, (2015), A Framework Strategy for a Resilient Energy Union with a Forward-Looking Climate Change Policy, COM/2015/080 final, Energy Union Package, available at: http://eur-lex.europa.eu/resource.html?uri=cellar:1bd46c90bdd4-11e4-bbe1-01aa75ed71a1.0001.03/DOC_1\&format=PDF, (accessed 12.03.2017).

- European Commission, (2015), Projects of common interest, available at: https://ec.europa.eu/energy/en/topics/infrastructure/projects-common-interest, (accessed 02.02.2017).

- European Energy Security Strategy (2014), EUR-lex, COM(2014) 330 final, available at:

http://eur-lex.europa.eu/legalcontent/EN/ALL/?uri=CELEX:52014DC0330\&qid=1407855611566, (accessed 02.02.2017). 
- European Policy Centre, (2007), “The New EU Energy Policy: Balancing the International Market and External Security of Supply". Policy Dialogue, (Event Report), January 29, available at: http://www.epc.eu/events_rep_details.php?cat_id=6\&pub_id=786, $\quad$ (accessed 11.02.2017).

- Green Paper - Towards a European strategy for the security of energy supply, COM/2000/0769 final, available at: $\underline{\text { http://eur-lex.europa.eu/legal- }}$ content/EN/TXT/?uri=CELEX:52000DC0769, (accessed 11.02.2017).

- HAFNER M. (2015), "Southern Gas Corridor and the EU security of supply: What's next?", Natural Gas Europe, available at: http://www.naturalgaseurope.com/southerngas-corridor-and-eu-gas-security-of-supply-22688, (accessed 20.03.2017).

- HAGHIGHI S. (2007), Energy Security: The External Legal Relations of the European Union with Major Oil- and Gas- Supplying Countries, Oregon: Hart Publishing.

- HEDBERG A. (2015), "EU's quest for energy security What role for the Energy Union?", European Policy Centre, available at: http://epc.eu/documents/uploads/pub_5374_eu_s_quest_for_energy_security.pdf, (accessed 20.03.2017).

- HELM D. (2004), The New Energy Paradigm, Oxford: Oxford University Press, p.441.

- International Energy Agency/OECD (2008), Energy in the Western Balkans, p. 35, available

https://www.iea.org/publications/freepublications/publication/balkans2008.pdf, (accessed 20.03.2017).

- KOINOVA E. (2008) "2007 in review: The EU: Year one...", The Sofia Echo, available at: http://sofiaecho.com/2008/01/04/658407_2007-in-review-the-eu-year-one, (accessed 11.02.2017).

- LEGRO J. W. and MORAVCSIK A. (1999), "Is Anybody Still a Realist?", International Security Vol. 24, Issue 2. 
- MATALUCCI S. (2015), "European Energy Union: A vision that still requires implementation", Natural Gas Europe, available at: http://www.naturalgaseurope.com/european-energy-union-unveiled-22355, (accessed 12.03.2017).

- OFFSHORE ABERDEEN (2015), International: Cedigaz expects European gas production to fall $2.1 \%$ annually to 2035 , available at: http://www.offshoreaberdeen.com/news/international-cedigaz-expects-european-gasproduction-to-fall-2-1-annually-to-2035,-offshore-aberdeen, (accessed, 03.03.2017).

- POIANA O. (2010), A Constructivist Approach to the security of the European Natural Gas Supply. The Black Sea Region and its Geopolitical Significance, Germany: VDM Publishing House, pp. 4-14.

- SOLORIO S. I. and MORARTA F. (2012), Introduction: the re-evolution of energy policy in Europe în European Energy Policy. An environment Approach, UK: Edward Elgar, Cheltenham Publishing Limited.

- The Lisbon Treaty (2007), Official Journal of the European Union, C306, Volume 50, available at: http://eur-lex.europa.eu/legalcontent/EN/TXT/PDF/?uri=OJ:C:2007:306:FULL\&from=EN, (accessed. 07.03.2017).

- UMBACH F. (2007), “The New EU Energy Policy: Balancing the intern Market and external security of supply”, German Council on Foreign Relations, Policy Dialogue 29 January

- UMBACH F. (2011), "The Black Sea Region and the Great Energy Game in Eurasia" in: BALCER Adam (ed.), The Eastern Partnership in the Black Sea Region: towards a New Synergy, Demos Europa, Center for European Policy.

- WAllace H., POlloCK M. A. and YOUNG A. R. (2010), Policy-Making in the European Union, New York: Oxford University Press.

- YOUNG R. (2009), Energy Security. Europe's new foreign policy, New York: Routledge. 